\title{
Symbolic Images Implied in The House on Mango Street from the Perspective of Feminism
}

\author{
Wang Fangyuan, Sun Yu, and Zhang Tong
}

\begin{abstract}
The House on Mango Street is a classical children book written by a Chicana feminist, Sandra Cisneros. This paper tries to analyze symbolic images implied in the book from the perspective of feminism. It is found that Cisneros describes the tragedy of women in a male dominant community through portraying house used to lock women, the clothesline and the window through which women contact the outside world. However, some women have awakened as the heroine Esperanza writes to find the inner space, refuses to receive the original lifestyle and decides to escape the Mango Street.
\end{abstract}

Index Terms-Feminism, symbolic images, The House on Mango Street.

\section{INTRODUCTION}

The House on Mango Street is a book written by a Chicana feminist writer Sandra Cisneros, which is composed of 44 short stories.

In The House on Mango Street, the author Sandra Cisneros employs many symbolic images to imply the double marginalized status of women and the hopes of the disadvantaged groups in this community. [1] There are various females live on Mango Street [2]. Through symbolic images, the readers can deeply feel the unfair treatment women suffer from. Besides, the awareness of gender equality and hopes for a better life is also implied.

\section{Social Status: House}

Latino female migrants are double marginalized in this society. Firstly, the Latino migrants live in a poor and uncomfortable community and are marginalized by the mainstream of the society. Secondly, women suffer from unfair treatment by males. "Females have to suffer from both the social pressure and oppression from males" [3]. The double marginalized tragedy is implied in the symbol of "house".

House is mentioned in a high frequency in this book. "Buildings are important for constructing social space" [4]. It is used to show the comparatively lower status of Latino migrants. At the beginning of the story, the little girl Esperanza tells us that the house on Mango Street is the residence of her family. They have moved for so many times that Esperanza fails to remember the exact times, but this

Manuscript received July 24, 2018; revised September 17, 2018. This work was supported by the Seed Foundation of Innovation and Creation for Graduate Students in Northwestern Polytechnical University under Grant ZZ2018244.

The authors are with Northwestern Polytechnical University, Xi'an, China (e-mail: 13201760150@163.com). house is different.

"The House on Mango Street is ours, and we don't have to pay rent to anybody, or share the yard with the people down stairs, or be careful not to make too much noise, and there isn't a landlord banging on the ceiling with a broom" [5].

Although this is the first house which belongs to them, Esperanza does not like it at all. As she claims, "it's not the house we'd thought we'd get" [5]. The house "is small and red. The window is small. Both the wall and door are old" [5]. From Esperanza's narration, we can feel that she is not satisfied with this house. Esperanza hates this house not only because it is shabby, but also for it is the representation of social status.

In the story The house on Mango Street 4, Esperanza recalls that a nun from her school once asks her "where do you live?", she has to admit that she lives in that shabby apartment. Esperanza says "it made me feel like nothing" [5]. After that, Esperanza says "In knew then I had to have a house, a real house. One I could point to" [5]. Her dissatisfaction with the house on Mango Street represents that she is ashamed of the shabby house and low status of Latino migrants.

Through narrating her impression on house, Esperanza expresses that she wants to own a decent house which can provide her with personal space. In their imagination, there is a dream house. According to the description, this house has "running water", "real stairs", "a basement and at least three washrooms" [5]. Besides, the house is white with trees. It has a great yard and grass growing without a fence. The dreaming house is the symbolic image of the dream for higher social status of Latino migrants. However, it is only "the house Papa talked about when he held a lottery ticket and mama dreamed up in the stories she told us before we went to bed" [5]. It shows that they are still far away from their equality dream.

House mentioned in The House on Mango Street is not only used to imply the lower social status of Latino migrants, but also to show the tragedy of double marginalized Latino women. There are both racial and gender differences in this community.

On the Mango Street, all women are bound in the house by males. The house is almost the prison for women. As she describes, "the boys and the girls live in separate world. The boys in their universe and we in ours" [5]. There is a vivid description in the story The Boys and Girls, Esperanza says she would always be that "red balloon tied to an anchor" [5]. It is also the symbolic image for all women on Mango Street.

Esperanza's great-grandmother is restricted in the house by her husband for the whole life. Esperanza tells us the story of her great-grand mother, "my great-grandfather threw a sack over her head and carried her off. Just that, as if she were a fancy chandelier. That's the way he did it" [5]. 
The status of women is so low that men can use such a barbaric way to get marriage. Even the little Esperanza realize the unfair treatment to women. In this story, it is said that females born in the Chinese year of horse, like her and her great-grandmother, are supposed to be bad luck, but she says "I think this is a Chinese lie because the Chinese, like the Mexicans, don't like their women strong" [5].

In another story named Cathy Queen of Cats, there is a lady whose name is Edna, "She used to own a building big as a whale" [5]. Edna has a younger brother. Her mother tells her brother not to sell this house. However, her brother sells that house as soon as she closed her eyes. It also implies that women has few voice. Men enjoy the absolute rights in every field.

Besides, Louie's girl cousin Marin is also restricted inside the house. In the story "Louie,His Cousin\&His Other Cousin", it is claimed that "She can't come out _gotta baby-sit with Louie's sisters" [5]. However, she is eager to contact the outside world. As it is mentioned in this story, "she stands in the doorway a lot, all the time singing, clicking her fingers" [5].

To some extent, Marin is a special girl in this community. She wants to attract boys. She says the important thing is let the boys see her and she can see them either. Esperanza also tells us that when the boys accost her, "Marin just looks at them without even blinking and is no afraid" [5].

However, although Marin is different from other girls on Mango Street and has the desire and courage to pursue her own place in the outside world, "she can only stay out in front" [5]. She fails to get absolute freedom in this community.

In addition, Esperanza has a little sister called Nenny. In the story The Boys and Girls 2, "She can't play with those Vargas kids or she will turn out just like them" [5]. it is implied that Nenny is not allowed to play with kids outside the house.

Little Sally suffers from the similar miserable life. "The boys at school think she is beautiful." However, "Her father says to be this beautiful is trouble", "then she can't go out" [5] Once, "Sally's father catches her talking to a boy and the next day she doesn't come to school. And the next" [5]. After that, Sally tells Esperanza her tragic experience, "he just went crazy, he just forget he was her father between the buckle and the belt" [5]. Sally loses the right to go to school and has to stay in the house.

The most typical one is Rafaela. She is always locked indoors by her husband "because her husband is afraid Rafaela will run away since she is too beautiful to look at" [5]. Being locked inside is her tragic fate.

House is a major symbolic images in the book. It is the symbol of social status. It implys not only the low status of Latino migrants, but also the miserable restricted lives of women in this community.

\section{YEARN FOR OUTSIDE: WINDOW AND CLOTHESLINE}

In The House on Mango Street, the male-dominated community, we can find the wife locked by her husband and the daughter beat by her father. They have to stay in houses and even suffer from cruelty. There exists two major symbolic images employed by women to contact the outside world.

In the story My Name, Esperanza tells us her great-grandmother. They have the same name. "In English my name means hope". In Spanish, "it means sadness, it means waiting" [5]. The tragic life of her great-grandmother is corresponding to its Spanish meaning. Her great-grandmother used to be "a wild horse of a woman" until her great-grandfather "threw a sack over her head and carried her off, as if she was a fancy chandelier" [5]. Her great-grandmother never forgives him and spends the whole life to look out of the outside world through window. As Esperanza describes, "and the story goes she never forgave him. She looked out the window her whole life, the way so many women sit their sadness on an elbow" [5].

Window represents a kind of door leading to the outside world. Her great-grandmother yearns for freedom for a whole life, but only owns a window.

There is not only one character who has to contact the outside world only through a window or a clothesline. In the story Rafaela Who Drinks Coconut and Papaya Juice on Tuesdays, the young lady Rafaela "gets locked indoors" by her husband because she is too beautiful [5]. She looks forward to the outside life, so "Rafaela leans out the window" and "a long time passes and we forget she is up there watching" [5]. She can communicate with the outside world only on each Tuesday, because her husband plays dominoes on that day. So every Tuesday, she gets an opportunity to contact the outside world.

"She throws a crumpled dollar down and always asks for coconut or sometimes papaya juice, and we send it up to her in a paper shopping bag she lets down with clothesline" [5].

She is eager to experience the outside life, but never plans to resist male authority. Her life is doomed to end in tragedy.

As women are restricted indoors, they contact the outside world through window or clothesline. Things like window or clothesline are not only the symbols of their desire for the outside world, but also set off the miserable lies of women. Although they eager to get equal rights as males, they never revolt to the male-dominated society.

\section{AWARENESS: NAME, WrITING AND LEAVING}

In The House on Mango Street, name is a symbolic image of life. In the story My Name, Esperanza tells us that she has the same name with her great-grandmother. Her great-grandmother is eager to freedom, but she is restricted inside the house for the whole life. Therefore, Esperanza says "I have inherited her name, but I don't want to inherit her place by the window" [5]. It shows that Esperanza refuses the life-style like her great-grandmother. She would revolt for freedom and dignity.

Realizing that she should find another life-style, Esperanza writes to help herself find the inner space. As she says, "I put it down on paper and then the ghost does not ache so much. I write it down and Mango says goodbye sometimes. She does not hold me with both arms. She sets me free" [5]. Through writing, Esperanza can temporarily keep shackles away. She finds calmness and freedom through writing. 
Esperanza wants to pursue a different life so she decides to leave Mango Street. “One day I will say goodbye to Mango. I am too strong for her to keep me here forever. One day I will go away" [5]. She does so because she concerns not only herself, but also her neighbors. Her purpose of leaving is illuminated in her narration. She hopes that "One day I'll own my own house" and "I'll offer them the attic, ask them to stay, because I know how it is to be without a house" [5]. It shows the little girl's dream of giving helpless people a favor. When she prepares to leave, she says, "They will not know I have gone away to come back. For the ones I left behind. For the ones who cannot out" [5]. Her leaving gives readers a hope of a better society.

\section{CONCLUSION}

Symbolic image plays an important role in this book. Social status is implied in the description of houses. Women live on Mango Street yearn for freedom and dignity, but they are restricted indoors and can only contact the outside world through window and clothesline. The miserable lives of women are embodied through employing symbolic images. Besides, through employing the symbolic images of name, writing and leaving, awareness of Esperanza brings readers hopes for achieving gender equality.

\section{ACKNOWLEDGMENT}

I sincerely hope I can express my thanks to all the people who help me during this research. Firstly, I want to express my sincerely gratitude to my supervisor, Professor Sun Yu. It is impossible for me to do researches without her help. Secondly, I'd like to thank the authors in references. They provide me research inspiration and relevant knowledge.

\section{REFERENCES}

[1] G. Robin, "Sandra Cisneros: Border crossings and beyond," Melus, vol. 19, no. 1, pp. 19-29, 1994.

[2] J. Che and Z. Wang, "Analysis of The House on Mango Street on multiple narrative perspectives and construction of cultural spaces," The World Literature Criticism, pp. 155-157, 2010.
[3] H. Wang, "A house of ones own: The pursuit of class, racial and gender identity on Cisneros' The House on Mango Street," Journal of Xidian University (Social Science Edition), vol. 20, no. 4, pp. 113-118, 2010.

[4] Y. Fang, "The space in literary narrative," Journal of Ningbo University (Liberal Arts Edition), vol. 29, no. 4, pp. 42-48, 2016.

[5] S. Cisneros, The House on Mango Street, Vintage, 2013. pp. 6-48.

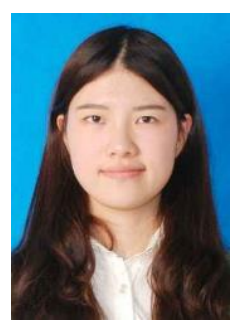

Wang Fangyuan was born in Hefei city, Anhui province in China on March 1st, 1995. She has got the bachelor's degree in Northwestern Polytechnical University, Xi'an city, China in June, 2017 with majored in English. She is pursuing for master's degree in Northwestern Polytechnical University since September, 2017, major in English literature now. Her major study field includes space narration, children literature, and immigrant literature.

She was a teaching assistant in the Middle School Attached to Northwestern Polytechniacal University during March and April in 2017; TOEFL teaching assistant in New Oriental during July and August in 2017; Internship in the People's Government of Shaanxi Province in winter vacation in 2018 .

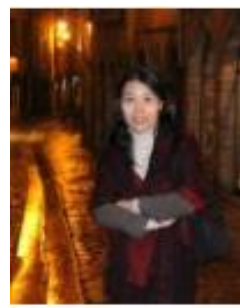

Sun Yu was born in Wuhan, Hubei Province, China. She got the bachelor's degree in Xi'an International Studies University in Xi'an, Shaanxi province in 1993, and got the master's degree in Northwestern Polytechnical University in Xi'an, Shaanxi province in 2000. Her major research field includes American literature, western culture, and translation.

She is a professor in School of Foreign Studies in the head of the Center for Arts Education in NPU.

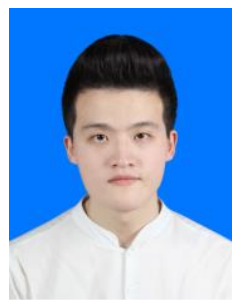

Zhang Tong was born on June 18th, 1995, Fuzhou city, Fujian province, China.

He has got his bachelor of arts in Northwestern Polytechnical University, Xi'an, China, In June, 2017. And he is pursuing the master's degree, majoring in applied linguistics in Northwestern Polytechnical University since September, 2017. His major Field of study is dialects.

He was a teaching assistant in the Middle School Attached to Northwestern Polytechnical University during March and April in 2017, and an assistant of Foreign Affairs Office of People's Government of Shaanxi Province. His current research interests include dialects. 